\title{
Sedative effect and physiological changes in horses treated with intramuscular injection of detomidine and morphine
}

\author{
Lucas Valeiras Gaddini ${ }^{*}$ (i) Carlos Rodrigo Komatsu de Alencar ${ }^{1}$ Taina Lorraine Pereira Azevedo ${ }^{1}$ \\ Gabriela Geraldo de Lima $^{1}$ Rubia Mitalli Tomacheuski ${ }^{3}$ (D) Marcos Ferrante ${ }^{2}$ (D) \\ Marilda Onghero Taffarel ${ }^{1}$ (D)
}

${ }^{1}$ Departamento de Medicina Veterinária, Universidade de Estadual de Maringá, Campus de Ciências Agrárias, 87507-190, Umuarama, PR, Brasil. E-mail: lucas_valeiras@hotmail.com. "Corresponding author.

${ }^{2}$ Departamento de Medicina Veterinária, Universidade Federal de Lavras (UFLA), Lavras, MG, Brasil.

${ }^{3}$ Departamento de Medicina Veterinária, Universidade Estadual Paulista Júlio de Mesquita Filho (UNESP), Botucatu, SP, Brasil.

ABSTRACT: This study aimed to elucidate the sedative effect and physiological changes associated with the intramuscular injection of detomidine combined with morphine in horses. Six healthy crossbred horses, aged 2 to 10 years, were included. A crossover experimental design was used to compare the effects of intramuscular injection of $30 \mu \mathrm{g} / \mathrm{kg}$ of detomidine alone (IMD) and intramuscular administration of $30 \mu \mathrm{g} / \mathrm{kg}$ of detomidine and $0.1 \mathrm{mg} / \mathrm{kg}$ of morphine (IMDM). The degree of sedation, height of head above ground, were assessed at the time points before and 5, 10, 20, 30, 40, 50, 60, 75, 90, 105, and 120 minutes after drug administration, and heart rate, respiratory rate, systolic blood pressure, rectum temperature and intestinal motility were assessed at the time points before and 10, 20, 30, 40, 50, 60, 75, 90, 105, and 120 minutes after drug administration. The physiological parameters were analyzed using the Kruskal-Wallis test with Dunn's post-hoc test and analysis of variance with t-test for independent samples and the sedation scores using the Friedman test and Mann Whitney U-test. P-values $<0.05$ indicated a statistically significant difference. IMDM promoted a higher sedative effect as compared to IMD, but the sedation occurred inconsistently. Additionally, a reduction in intestinal motility was observed with IMDM at 60, 75, 90, and 105 minutes after administration. IMDM promoted more variable sedation and prolonged reduction in the intestinal motility in the horses as compared to IMD.

Key words: deep sedation, horses, hypnotics and sedatives, detomidine, morphine.

Efeito sedativo e alterações fisiológicas em cavalos tratados com injeção intramuscular de detomidina e morfina

RESUMO: Este trabalho teve por objetivo elucidar o efeito sedativo e alterações fisiológicas em cavalos associados à injeção intramuscular de detomidina combinada com morfina. Seis cavalos saudáveis e sem raça definida, com idade de dois a 10 anos, foram incluidos. Delineamento experimental cruzado foi usado para comparar os efeitos da administração intramuscular de 30 ug/kg detomidina isolada (IMD) e da administração intramuscular de $30 \mu \mathrm{g} / \mathrm{kg}$ de detomidina associada à morfina a $0,1 \mathrm{mg} / \mathrm{kg}$ (IMDM). Avaliou-se o grau de sedação, a altura da cabeça acima do solo nos momentos antes (M0) e 5, 10, 20, 30, 40, 50, 60, 75, 90, 105 e 120 minutos após administração dos fármacos, e frequência cardiaca, frequência respiratória, pressão arterial sistólica, temperatura retal e motilidade intestinal foram avaliados nos momentos antes (M0) e 10, 20, 30, 40, 50, 60, 75, 90, 105 e 120 minutos após administração dos fármacos. Para análise estatística foram utilizados: teste de Kruskal-Wallis, com pós-teste de Dunn, e ANOVA associada ao teste t para amostras independentes para os parâmetros fisiológicos; e teste de Friedman e teste de Mann Whitney para os escores de sedação. Valores de P $<0.05$ indicaram diferença significativa. A administração de detomidina associada à morfina pela via intramuscular (IM) promoveu maior efeito sedativo, quando comparada à administração isolada de detomidina IM. Contudo, a sedação ocorreu de forma inconsistente. Também foi observado, no IMDM, redução da motilidade intestinal aos 60, 75, 90 e 105 minutos de avaliação. A associação de morfina e detomidina pela via intramuscular promove sedação de forma variável em cavalos, e resulta em redução da motilidade intestinal, mais prolongada quando comparada a administração isolada de detomidina intramuscular.

Palavras-chave: profundidade sedativa, cavalos, hipnóticos e sedativos, detomidina, morfina.

\section{INTRODUCTION}

Stressed and poorly mannered horses are commonly seen in clinical and surgical practice. The use of sedative drugs in these animals not only facilitates and increases the safety of performing diagnostic or surgical procedures with the animal in the standing position (TAINTOR et al., 2016), but also minimizes the risks of general anesthesia (DUGDALE \& TAYLOR, 2016). The $\alpha 2$-adrenergic 
receptor agonists, such as detomidine, are the most commonly used drugs for sedation in horses (FIELDING et al., 2006), as they provide a reliable, stable, and deep sedation degree in this species (GRIMSRUD et al., 2014). The clinical and adverse effects appear to be dependent on the drug dose and administration route, which tend to be more intense when it is administered intravenously (GRIMSRUD et al., 2014).

The combination use of opioids and $\alpha 2$ adrenergic agonists is quite common. This induces neuroleptoanalgesia, promotes a higher degree of sedation and analgesia, and has a prolonged effect (SOLANO et al., 2009; GOZALO-MARCILLA et al., 2017). In donkeys, the intramuscular administration of detomidine $(60 \mu \mathrm{g} / \mathrm{kg})$ with butorphanol $(50 \mu \mathrm{g} /$ $\mathrm{kg}$ ) resulted in a sedative effect in all the animals, with 10-minute latency and a mean sedation time of $38.8 \pm$ 5.2 minutes (EVANGELISTA et al., 2018). In a captive zebra (Equus burchelli boehmi), the combination of detomidine $(30 \mu \mathrm{g} / \mathrm{kg})$ and acepromazine $(0.02 \mathrm{mg} /$ $\mathrm{kg}$ ) resulted in a sedative effect 15 minutes after administration (BHARATHIDASAN, 2015). Other studies investigated the sedative effect of intravenous detomidine in combination with opioids such as buprenorphine, morphine, and methadone in horses (TAYLOR et al., 2014; GUILHEN et al., 2015; POTTER et al., 2016; GOZALO-MARCILLA et al., 2017).

A previous study compared the sedative and physiological effects of detomidine administered intravenously and intramuscularly in horses (MAMA et al., 2009). Therefore, this study aimed to elucidate the sedative effect and physiological variables of intramuscularly administered detomidine with morphine in horses, as there are no studies on this in the literature. The hypothesis is that intramuscular administration of detomidine with morphine promotes greater sedation than the intramuscular administration of detomidine alone.

\section{MATERIALS AND METHODS}

Six adult horses weighing $355 \mathrm{~kg}( \pm 42)$, aged between 2 and 10 years, and considered healthy after clinical and laboratory examinations (complete blood count) were included in this study, regardless of the breed and sex. The horses underwent a 3-week adaptation process to adapt to the place of study and the people involved in the experiment, such as evaluators and those responsible for handling and instrumentation the animals.

In this crossover design, the horses were subjected to two experimental sedation methods with a washout period of 7 days (GRIMSRUD et al., 2009). The methods included intramuscular administration of $30 \mu \mathrm{g} / \mathrm{kg}$ of detomidine (Dormiun V - Agener União Saúde Animal ${ }^{\circledR}$, São Paulo, SP, Brazil) (IMD) and intramuscular administration of 30 $\mu \mathrm{g} / \mathrm{kg}$ of detomidine in combination with $0.1 \mathrm{mg} / \mathrm{kg}$ of morphine (Dimorf - Cristália Produtos Químicos Farmacêuticos Ltda ${ }^{\circledR}$, São Paulo, SP, Brazil) (IMDM).

In the pre-experimental period, the horses were taken to the experimental site and weighed. Following this, catheterization of the right jugular vein was performed with a 14-gauge caliber catheter $\left(\right.$ Jelco $^{\circledR}$, USA), as a safety measure, in case intervention was needed in any emergency situation during the experimental period. During the experimental period, the horses were housed in a containment stall, where they remained until the end of the evaluation period. After the experiment, the horses were returned to the pasture or stall.

The sedation was assessed by measuring the height of head above ground (HHAG) from the level of the lower lip to the ground using a tape measure present in the containment bay next to the animal's head (RINGER et al., 2012; MARLY et al., 2014). Subsequently, the numerical rating scale (NRS) proposed by RINGER et al. (2013) was applied to assess postural instability and behavioral responses based on visual, tactile, and sound stimulations. These variables were assessed at the time points before (M0) and 5, 10, 20, 30, 40, 50, 60, 75, 90, 105, and 120 minutes after administration of the drugs (M5 to M120, respectively) by an evaluator blinded to the treatment.

The tactile stimulation was gentle, gradually increasing pressure for 3 seconds against the coronary band of the pelvic limb, using a pole with a blunt nail, and the reaction was scored using the NRS. Visual stimulation was performed by opening an umbrella in front of the horse, acoustic stimulation was assessed and scored with a palm clap outside the animal's visual field, and postural instability was assessed and scored using the NRS (Table 1) (RINGER et al., 2013).

Occurrence of any adverse effects was assessed by measuring the following physiological parameters: heart rate and respiratory rate assessed with a stethoscope for a period of 1 minute (MASSONE, 2011); non-invasive systolic blood pressure measured using the Doppler method (Parks Medical $^{\circledR}$, Nevada, USA) at the coccygeal artery with a cuff size $40 \%$ of the width of the animal's tail circumference (MASSONE, 2011); rectal temperature measured using a digital clinical thermometer; and intestinal motility assessed by auscultation of the 
Table 1 - Numerical rating scale scores assessing sedation in horses with scores for postural instability and behavioral responses based on tactile, visual, and sound stimulations (adapted from RINGER et al., 2013).

\begin{tabular}{|c|c|c|c|c|}
\hline NRS & $\begin{array}{l}\text { Postural } \\
\text { instability }\end{array}$ & Tactile stimulation & Visual stimulation & Acoustic stimulation \\
\hline 0 & $\begin{array}{l}\text { No signs of } \\
\text { instability }\end{array}$ & $\begin{array}{l}\text { Exaggerated reaction after light } \\
\text { pressure: fast movement of the leg }\end{array}$ & $\begin{array}{c}\text { Undiminished response, } \\
\text { animal moves away vigorously }\end{array}$ & $\begin{array}{l}\text { Undiminished response, animal } \\
\text { turns vigorously }\end{array}$ \\
\hline 1 & $\begin{array}{c}\text { Stable but } \\
\text { swaying slightly }\end{array}$ & $\begin{array}{c}\text { Animal elevates the front leg after } \\
\text { normal pressure }\end{array}$ & $\begin{array}{l}\text { Muted response, subdued } \\
\text { reaction and movements }\end{array}$ & $\begin{array}{l}\text { Muted response, subdued reaction } \\
\text { and movements }\end{array}$ \\
\hline 2 & Swaying clearly & $\begin{array}{l}\text { Slightly diminished response with } \\
\text { normal to strong pressure }\end{array}$ & $\begin{array}{c}\text { Reaction significantly } \\
\text { subdued, elevates head slightly }\end{array}$ & $\begin{array}{c}\text { No appreciable response, but } \\
\text { evidence of hearing (movement of } \\
\text { ears) }\end{array}$ \\
\hline 3 & $\begin{array}{l}\text { Nearly falling } \\
\text { down }\end{array}$ & $\begin{array}{l}\text { No response even with strong } \\
\text { pressure }\end{array}$ & No signs of visual arousal & No sign of noise recognition \\
\hline 4 & $\begin{array}{l}\text { Horse falling } \\
\text { down }\end{array}$ & & & \\
\hline
\end{tabular}

NRS, Numerical rating scale.

four abdominal quadrants and using a score system described by (GOMES \& FILHO 2012). These parameters were measured by a second evaluator blinded to the treatment at M0 and from M10 to M120 after administration of the drugs.

For statistical analysis, the non-parametric data were tested using the Kruskal-Wallis test with Dunn's post-hoc test, analysis of variance associated with the t-test for independent samples, and the Shapiro Wilk normality test for the physiological parameters. The Friedman test and Mann Whitney U-test were performed for the sedation scores compared over time from M0. P-values $<0.05$ indicated a significant difference. Data were analyzed using BioEstat 5.3 (free software, Instituto de Desenvolvimento Sustentável Mamirauá, Brazil).

\section{RESULTS AND DISCUSSION}

The effects of sedation present different characteristics with respect to depth, quality of sedation, and degree of ataxia, which represents the individual responses of the horses (SCHAUVLIEGE et al., 2019). The responses to tactile, visual, and auditory stimulations predict how the horse would respond to a clinical or surgical procedure under sedation, representing the quality of sedation (RINGER et al., 2013; GOZALO-MARCILLA et al., 2017). Thus, theoretically, the sedation scale used in this study should assess these different aspects. The results showed no increase in the sedation scores of the animals receiving IMD or IMDM as compared to the M0 scores (Table 2). Furthermore, IMDM did not present more intense sedation than that of IMD, and neither IMDM nor IMD changed the sedation scores obtained at MO.

HHAG and postural instability are the parameters used to assess the depth of sedation (RINGER et al., 2013; MARLY et al., 2014). There was a significant reduction in the HHAG over time with IMDM ( $<<0.0001)$ at M30, M40, M50, and M60 as compared to M0 (Table 2), but there was no change in this parameter with IMD. Additionally, there was no difference observed between IMD and IMDM.

Considering that a reduction in HHAG of $\geq 50 \%$ of the value presented when awake indicates sedation (RINGER et al., 2012; MARLY et al., 2014), it was possible to observe sedation in animals after being subjected to IMD and IMDM. In the IMD group, only two animals presented sedation values, starting after 10 minutes and continuing up to M75 and M105. In the IMDM group, four animals presented sedation values, starting at M40, M50, $\mathrm{M} 20$, and M10 and continuing up to M60, M50, M75, and M60, respectively. Although both the proposed methods achieved some degree of sedation, only the IMDM group demonstrated a significant reduction in HHAG, which is characteristic of sedation with $\alpha 2-$ adrenergic agonists (RINGER et al., 2012; MARLY et al., 2014).

Although the addition of morphine promoted sedation in $66 \%$ of the animals, it was inconsistent with respect to the onset and duration of the effect. These results differ from those of another study that evaluated the addition of opioids such as morphine $(0.1 \mathrm{mg} / \mathrm{kg})$, methadone $(0.1 \mathrm{mg} /$ 
Table 2 - Comparison of the scores of the tactile, visual, and acoustic stimuli responses and mean reduction in head height above ground in horses subjected to intramuscular detomidine administration and intramuscular detomidine with morphine administration.

\begin{tabular}{|c|c|c|c|c|c|c|c|c|}
\hline \multirow{3}{*}{$\begin{array}{l}\text { Time } \\
\text { point }\end{array}$} & \multicolumn{6}{|c|}{ 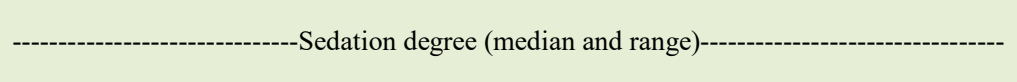 } & \multicolumn{2}{|c|}{$\begin{array}{l}\text { Head height above ground } \\
\text { (percentage of reduction) }\end{array}$} \\
\hline & \multicolumn{3}{|c|}{------------------------IMD----------------------- } & \multicolumn{3}{|c|}{-----------------------IMDM--------------------- } & IMD & IMDM \\
\hline & Tactile & Visual & Acoustic & Tactile & Visual & Acoustic & & \\
\hline 0 & $0(0-0)$ & $0(0-0)$ & $0(1-0)$ & $0(1-0)$ & $0(1-0)$ & $0(1-0)$ & $0 \pm 0$ & $0 \pm 0$ \\
\hline 5 & $0(1-0)$ & $0.5(1-0)$ & $0.5(2-0)$ & $0(1-0)$ & $0(0-0)$ & $0(1-0)$ & $12.7 \pm 29.3$ & $6.8 \pm 7.5$ \\
\hline 10 & $0(3-0)$ & $0(3-0)$ & $0(2-0)$ & $0(1-0)$ & $0(1-0)$ & $0(1-0)$ & $27.6 \pm 35.9$ & $24.8 \pm 13.4$ \\
\hline 20 & $0.5(2-0)$ & $0.5(3-0)$ & $0.5(2-0)$ & $0(3-0)$ & $1(2-0)$ & $1(2-0)$ & $40.8 \pm 32.7$ & $40.3 \pm 25.9$ \\
\hline 30 & $0(2-0)$ & $1(3-0)$ & $0.5(3-0)$ & $0(3-1)$ & $1(2-0)$ & $1(2-0)$ & $40.3 \pm 31.5$ & $45.8 \pm 20.5^{*}$ \\
\hline 40 & $1(2-0)$ & $0.5(3-0)$ & $1(2-0)$ & $1(3-1)$ & $0.5(2-1)$ & $1(2-1)$ & $43.7 \pm 28.5$ & $53.6 \pm 17.8^{*}$ \\
\hline 50 & $0.5(2-0)$ & $1(3-0)$ & $1(3-0)$ & $0.5(2-1)$ & $0.5(2-0)$ & $1(2-0)$ & $43.5 \pm 24.8$ & $50.1 \pm 15.3^{*}$ \\
\hline 60 & $0(1-0)$ & $0(3-0)$ & $0.5(2-0)$ & $1(2-1)$ & $1(2-1)$ & $1(2-0)$ & $39.3 \pm 26.0$ & $48.1 \pm 17.1^{*}$ \\
\hline 75 & $0(1-0)$ & $0(2-0)$ & $1(2-0)$ & $0(2-0)$ & $0(2-0)$ & $1(2-0)$ & $31.8 \pm 26.9$ & $37.7 \pm 16.7$ \\
\hline 90 & $0(2-0)$ & $0(2-0)$ & $0.5(2-0)$ & $0.5(2-0)$ & $0.5(2-0)$ & $0(2-0)$ & $26.6 \pm 16.8$ & $26.6 \pm 8.1$ \\
\hline 105 & $0(1-0)$ & $0(2-0)$ & $0(2-0)$ & $0(2-0)$ & $0(2-0)$ & $0(2-0)$ & $23.0 \pm 22.7$ & $23.8 \pm 14.8$ \\
\hline 120 & $0(0-0)$ & $0(1-0)$ & $0(2-0)$ & $0(1-0)$ & $0(1-0)$ & $0(1-0)$ & $18.8 \pm 28.5$ & $15.4 \pm 8.7$ \\
\hline
\end{tabular}

* indicates difference when compared to baseline.

$\mathrm{IMD}$, intramuscular detomidine administration $(30 \mu \mathrm{g} / \mathrm{kg})$; IMDM, intramuscular detomidine with morphine administration $(30 \mu \mathrm{g} / \mathrm{kg}$ of detomidine and $0.1 \mathrm{mg} / \mathrm{kg}$ of morphine).

$\mathrm{kg})$, and butorphanol $(0.05 \mathrm{mg} / \mathrm{kg})$ after intravenous detomidine administration $(10 \mu \mathrm{g} / \mathrm{kg})$ in horses and observed greater sedation and lesser responsiveness to external stimuli as compared to detomidine alone (CLARKE \& PATON, 1988). Nevertheless, another study concluded that although the use of methadone $(0.2 \mathrm{mg} / \mathrm{kg})$ potentiated the antinociceptive effect produced by intravenous detomidine administration (5 $\mu \mathrm{g} / \mathrm{kg}$ ), it did not produce greater sedative effects than that of detomidine alone (GOZALOMARCILLA et al., 2017). The outcomes observed could be attributed to the intramuscular route of administration, which is associated with a lower plasma peak and a longer time to attain maximum drug concentration (MAMA et al., 2009; DEVINE et al., 2013). The variation in HHAG of the IMD group was similar to that in the study by MAMA et al. (2009) that compared the effects of intravenous and intramuscular administration of $30 \mu \mathrm{g} / \mathrm{kg}$ of detomidine. In that study, higher sedative effects were observed at 10 minutes in the animals receiving intravenous administration and at 60 minutes in those receiving intramuscular administration.

Table 3 presents the data on the physiological parameters. The common adverse effects of $\alpha 2$ adrenergic agonists include bradycardia, seconddegree atrioventricular block, and hypertension followed by hypotension (MEDEIROS et al., 2017).
These effects are influenced by the dose and routes of administration (GRIMSRUD et al., 2014). Several studies have shown that the administration of opioids, such as morphine at doses of $0.12 \mathrm{mg} / \mathrm{kg}$ (MUIR et al., 1978) and $0.66 \mathrm{mg} / \mathrm{kg}$ (KALPRAVIDH et al., 1984), meperidine at $1.1 \mathrm{mg} / \mathrm{kg}$, oxymorphone at $0.03 \mathrm{mg} / \mathrm{kg}$, methadone at $0.12 \mathrm{mg} / \mathrm{kg}$ (MUIR et al., 1978), and buprenorphine at $3.0 \mathrm{mg} / \mathrm{kg}$ and $10.0 \mathrm{mg} /$ kg (SZOKE et al., 1998; CARREGARO et al., 2006), increased the heart rate and/or blood pressure for variable periods. In the study by MAMA et al. (2009), IMD $(30 \mu \mathrm{g} / \mathrm{kg})$ presented a difference in the heart rate from that of the baseline only at M30, whereas in this study, only IMDM promoted a reduction in the heart rate due to the depressive effect of the $\alpha 2$ adrenergic agonist. Compared to the baseline time point, the IMDM promoted a significant reduction in the heart rate at M30.

Respiratory depression was expected in this study because of the use of both opioids and $\alpha 2$-adrenergic agonist (CLUTTON, 2010). In both groups, there was a reduction in the respiratory rate as compared to the initial value (Table 3), with no difference between IMD and IMDM. Unlike the study by Devine et al. (2013), no differences were found in the respiratory rate of the horses treated with $0.1 \mathrm{mg} / \mathrm{kg}$ morphine intramuscularly. However, the arterial blood gas analysis could provide a more adequate assessment 
Table 3 - Comparison of the heart rate, respiratory rate, systolic arterial pressure, and degree of intestinal motility in horses subjected to intramuscular detomidine administration and intramuscular detomidine with morphine administration.

\begin{tabular}{|c|c|c|c|c|c|c|c|c|}
\hline \multirow[b]{2}{*}{ Time point } & \multicolumn{2}{|c|}{-------Heart rate------ } & \multicolumn{2}{|c|}{---------Respiratory rate---------- } & \multicolumn{2}{|c|}{-Systolic arterial pressure- } & \multicolumn{2}{|c|}{----------Intestinal motility------. } \\
\hline & IMD & IMDM & IMD & IMDM & IMD & IMDM & IMD & IMDM \\
\hline 0 & $49 \pm 9$ & $50 \pm 11$ & $25.4 \pm 7.1$ & $25.4 \pm 8.9$ & $110 \pm 11$ & $101 \pm 14$ & $11(12-8)$ & $9(12-8)$ \\
\hline 10 & $39 \pm 14$ & $37 \pm 11$ & $16.7 \pm 9.3$ & $15.3 \pm 5.8$ & $118 \pm 15$ & $103 \pm 14$ & $8(12-6)$ & $8(9-4)$ \\
\hline 20 & $42 \pm 19$ & $34 \pm 3$ & $14.7 \pm 6.0$ & $13.3 \pm 3.9$ & $118 \pm 21$ & $102 \pm 14$ & $7(10-5)$ & $6.5(8-4)$ \\
\hline 30 & $35 \pm 12$ & $32 \pm 5^{*}$ & $14.0 \pm 5.5$ & $12.0 \pm 2.5^{*}$ & $105 \pm 13$ & $91 \pm 15$ & $6.5(10-4)$ & $5(8-4)$ \\
\hline 40 & $35 \pm 8$ & $33 \pm 3$ & $13.3 \pm 6.0^{*}$ & $12.7 \pm 2.7$ & $110 \pm 17$ & $98 \pm 19$ & $7(9-4)$ & $4(8-4)$ \\
\hline 50 & $33 \pm 6$ & $33 \pm 3$ & $12.7 \pm 3.7^{*}$ & $12.3 \pm 3.2$ & $114 \pm 22$ & $95 \pm 20$ & $6.5(8-5)$ & $5(8-4)$ \\
\hline 60 & $34 \pm 6$ & $35 \pm 2$ & $13.0 \pm 3.5^{*}$ & $13.3 \pm 3.0$ & $103 \pm 14$ & $94 \pm 17$ & $6(9-4)$ & $4(8-4)^{*}$ \\
\hline 75 & $37 \pm 10$ & $37 \pm 2$ & $13.3 \pm 3.3$ & $13.3 \pm 3.0$ & $102 \pm 17$ & $93 \pm 16$ & $6.5(8-4)$ & $5.5(7-4)^{*}$ \\
\hline 90 & $35 \pm 2$ & $38 \pm 5$ & $14.3 \pm 3.7$ & $13.7 \pm 3.2$ & $101 \pm 19$ & $85 \pm 16$ & $6(8-5)$ & $4.5(7-4)^{*}$ \\
\hline 105 & $39 \pm 9$ & $40 \pm 6$ & $14.3 \pm 2.7$ & $15.0 \pm 3.3$ & $94 \pm 13$ & $89 \pm 18$ & $7(8-4)$ & $4.5(6-4)^{*} \dagger$ \\
\hline 120 & $39 \pm 3$ & $44 \pm 8$ & $14.8 \pm 4.4$ & $16.0 \pm 2.2$ & $98 \pm 13$ & $91 \pm 14$ & $7(8-4)$ & $6(8-4)$ \\
\hline
\end{tabular}

* indicates difference when compared to baseline; $\uparrow$ indicates difference from the IMD.

IMD, intramuscular detomidine administration $(30 \mu \mathrm{g} / \mathrm{kg})$; IMDM, intramuscular detomidine with morphine administration $(30 \mu \mathrm{g} / \mathrm{kg}$ of detomidine and $0.1 \mathrm{mg} / \mathrm{kg}$ of morphine).

A reduction in the intestinal motility was observed with both IMD and IMDM (Table 3). The reduction in motility in horses can occur with the use of $\alpha 2$-adrenergic agonists (de VRIES et al., 2016). However, the reduction in motility promoted by opioids reported in the literature is contradictory. According to DEVINE et al. (2013), the administration of morphine at a dose of $0.1 \mathrm{mg} / \mathrm{kg}$ did not reduce the intestinal motility in horses, whereas higher doses of 0.5 or $1 \mathrm{mg} / \mathrm{kg}$ may cause a decrease in the cecocolic activity (CLUTTON, 2010). In this study, IMDM reduced intestinal motility for up to 105 minutes. This could be attributed to the synergistic effect of opioids and $\alpha 2$-adrenergic agonists on intestinal motility, as well as the dose-dependent reduction with a combination of detomidine and methadone (GOZALO-MARCILLA et al., 2017).

\section{CONCLUSION}

Although IMDM provided variable sedation in the horses, the results presented an acceptable degree of sedation for clinical use. It did not generate any significant variations in the physiological variables and resulted in a more prolonged reduction in intestinal motility in the horses as compared to IMD. funding sponsors had no role in the design of the study, collection, analyses, and interpretation of data, writing of the manuscript, and decision to publish the results.

\section{BIOETHICS AND BIOSSECURITY COMMITTEE APPROVAL}

This study was approved by the Ethical Committee for the Use of Animals in Research under the protocol 2112040619.

\section{AUTHORS' CONTRIBUTIONS}

Gaddini and Taffarel conceived and designed experiments. Gaddini, de Alencar, de Lima and Azevedo performed the experiments. Taffarel supervised and coordinated the animal experiments. Gaddini, Taffarel and Ferrante performed statistical analyses of experimental data. Gaddini, Taffarel and Tomacheuski prepared the draft of the manuscript. All authors critically revised the manuscript and approved of the final version.

\section{REFERENCES}

BHARATHIDASAN, M., et al. A. Standing Sedation with Detomidine - Acepromazine and Low dose of Ketamine for Hoof Trimming in a Captive Zebra (Equusburchelliboehmi) - A Case Report. ZOO's PRINT. v.30, p.35-37, 2015. Available from: <https://www. zoosprint.org/ZooPrintMagazine/2015/January/ZPM_Jan_2015 Full magazine.pdf\#page=35>. Accessed: Dec. 20, 2019.

CARREGARO, A, B., et al. Cardiopulmonary effects of buprenorphine in horses. American Journal of Veterinary 
Research. v.67, p.1675-1680, 2006. Available from: <https:// doi.org/10.2460/ajvr.67.10.1675>. Accessed: Dec. 20, 2019. doi: 10.2460/ajvr.67.10.1675.

CLARKE, K, W., et al. Combined use of detomidine with opiates in the horse. Equine Veterinary Journal. 1988. v.20, n.5, p.331334. Available from: <https://doi.org/10.1111/j.2042-3306.1988. tb01540.x>. Accessed: Dec. 20, 2019. doi: 10.1111/j.20423306.1988.tb01540.x.

CLUTTON, R, E. Opioid analgesia in horses. Veterinary Clinics of North America: Equine Practice. v.26, p.493-514, 2010. Available from: <https://doi.org/10.1016/j.cveq.2010.07.002>. Accessed: Dec. 20, 2019. doi: 10.1016/j.cveq.2010.07.002.

DE VRIES, A., et al. O, M. Clinical effects and pharmacokinetic variables of romifidine and the peripheral $\alpha 2$ - adrenoceptor antagonist MK-467 in horses. Veterinary Anaesthesia and Analgesia. v.43, p.599-610, 2016. Available from: <https://doi.org/10.1111/ vaa.12354>. Accessed: Dec. 20, 2019. doi: 10.1111/vaa.12354.

DEVINE, E, P., et al. Pharmacokinetics of intramuscularly administered morphine in horses. Journal of the American Veterinary Medical Association. v.243, p.105-112, 2013. Available from: <https://doi.org/10.2460/javma.243.1.105>. Accessed: Dec. 20, 2019. doi: 10.2460/javma.243.1.105.

DUGDALE, A, H.; TAYLOR, P, M. Equine anaesthesia-associated mortality: where are we now? Veterinary Anaesthesia and Analgesia. v.43, p.242-255, 2016. Available from: $<$ https://doi. org/10.1111/vaa.12372>. Accessed: Dec. 20, 2019. doi: 10.1111/ vaa. 12372 .

EVANGELISTA, F., et al. A. Sedative and respiratory effects of intramuscular detomidine and butorphanol in donkeys sedated for bronchoalveolar lavage, Journal of Equine Veterinary Science. v.69, p.96-101, 2018. Available from: <https://doi.org/10.1016/j. jevs.2018.06.011>. Accessed: Dec. 20, 2019. doi: 10.1016/j. jevs.2018.06.011.

FIELDING, C, L., et al. Pharmacokinetics and 263 clinical effects of a sub anesthetic continuous rate infusion of ketamine in awake horses. American Journal Veterinary. v.67, p.1484-1490, 2006. Available from: <https://doi.org/10.2460/ajvr.67.9.1484>. Accessed: Dec. 20, 2019. doi: 10.2460/ajvr.67.9.1484.

GOMES, C, L, N.; RIBEIRO FILHO, J, D. Laxative effects of polyethylene glycol 3350 and electrolyte solutions in equines. Arquivo Brasileiro de Medicina Veterinária e Zootecnia. v.64, p.833-840, 2012. Available from: $<$ https://doi.org/10.1590/S010209352012000400007>. Accessed: Dec. 20, 2019. doi: 10.1590/ S0102-09352012000400007.

GOZALO-MARCILLA, M., et al. Sedative and antinociceptive effects of different combinations of detomidine and methadone in standing horses, Veterinary Anaesthesia and Analgesia. v.44, p.1116-1127, 2017. Available from: <https://doi.org/10.1016/j. vaa.2017.03.009>. Accessed: Dec. 20, 2019. doi: 10.1016/j. vaa.2017.03.009.

GRIMSRUD, K, N., et al. Pharmacokinetic and pharmacodynamic analysis comparing diverse effects of detomidine, medetomidine, and dexmedetomidine in the horse: a population analysis. Journal of Veterinary Pharmacology and Therapeutics. v.38, p.24-34, 2014. Available from: <https://doi.org/10.1111/jvp.12139>. Accessed: Dec. 20, 2019. doi: 10.1111/jvp.12139.
GRIMSRUD, K, N., et al. Pharmacokinetics of detomidine and its metabolites following intravenous and intramuscular administration in horses. Equine Veterinary Journal. v.41, p.361-365, 2009. Available from: <https://doi.org/10.2746/042516409X370900>. Accessed: Dec. 20, 2019. doi: 10.2746/042516409X370900.

GUILHEN, R, C., et al. A comparison of detomidine in combination with saline, morphine or methadone in horses submitted to experimental oral stimuli. Semina: Ciências Agrárias. v.36 p.4225-4236, 2015. Available from: <https://doi. org/10.5433/1679-0359.2015v36n6Supl2p4225>. Accessed: Dec. 20, 2019. doi: 10.5433/1679-0359.2015v36n6Sup12p4225.

KALPRAVIDH, M., et al. Effects of butorphanol, flunixin, levorphanol, morphine, and xylazine in ponies. American Journal of Veterinary Research. v.45, p.217-223, 1984. Available from: $<$ https:// europepmc.org/article/med/6711945>. Accessed: Dec. 20, 2019.

MAMA, K, R., et al. Plasma concentrations, behavioral and physiological effects following intravenous and intramuscular detomidine in horses. Equine Veterinary Journal. v.41, p.772-777, 2009. Available from: <https://doi. org/10.2746/042516409X421624>. Accessed: Dec. 20, 2019. doi: $10.2746 / 042516409 X 421624$.

MARLY, C., et al. Evaluation of a romifidine constant rate infusion protocol with or without butorphanol for dentistry and ophthalmologic procedures in standing horses. Veterinary Anaesthesia and Analgesia. v.41, p.491-497, 2014. Available from: <https://doi.org/10.1111/ vaa.12174>. Accessed: Dec. 20, 2019. doi: 10.1111/vaa.12174.

MASSONE, F. Anestesiologia Veterinária: farmacologia e técnicas. $6^{\circ}$ Edição. Rio de Janeiro:Guanabara Koogan, 2011. 448 p.

MEDEIROS, L, Q., et al. Sedative and cardiopulmonary effects of dexmedetomidine infusions randomly receiving, or not, butorphanol in standing horses. Veterinary Record. v.181, p.402, 2017. Available from: <https://doi.org/10.1136/vr.10435>. Accessed: Dec. 20, 2019. doi: 10.1136/vr.10435.

MUIR, W, W., et al. Cardiopulmonary effects of narcotic agonists and a partial agonist in horses. American Journal of Veterinary Research. v.39, p.1632-1635, 1978. Available from: <https:// europepmc.org/article/med/717878>. Accessed: Dec. 20, 2019.

NYMAN, G., et al. Effect of sedation with detomidine and butorphanol on pulmonary gas exchange in the horse. Acta Veterinaria Scandinavica. v.51, p.22, 2009. Available from: $<$ https://doi.org/ 10.1186/1751-0147-51-22>. Accessed: Dec. 20, 2019. doi: 10.1186/1751-0147-51-22.

POTTER, J, J., et al. Preliminary investigation comparing a detomidine continuous rate infusion combined with either morphine or buprenorphine for standing sedation in horses. Veterinary Anaesthesia and Analgesia. v.43, p.189-194, 2016. Available from: <https://doi.org/10.1111/vaa.12316>. Accessed: Dec. 20, 2019. doi: 10.1111/vaa.12316.

RINGER, S, K., et al. Development of a xylazine constant rate infusion with or without butorphanol for standing sedation of horses. Veterinary Anaesthesia and Analgesia, v.1, p.11, 2012. Available from: $\quad<$ https://doi.org/10.1111/j.1467-2995.2011.00653.x>. Accessed: Dec. 20, 2019. doi: 10.1111/j.1467-2995.2011.00653.x.

RINGER, S, K., et al. The effects of a loading dose followed by Constant rate infusion of xylazine compared with romifidine on 
sedation, ataxia and response to stimuli in horses. Veterinary Anaesthesia and Analgesia. v.40 p.157-165, 2013. Available from: $\quad<$ https://doi.org/10.1111/j.1467-2995.2012.00784.x >. Accessed: Dec. 20, 2019. doi: 10.1111/j.1467-2995.2012.00784.x.

SCHAUVLIEGE, S., et al. How to score sedation and adjust the administration rates of sedatives in horses: a literature review and introduction of the Ghent Sedation Algorithm. Veterinary Anaesthesia and Analgesia. v.46, p.4-13, 2018. Available from: $<$ https://doi.org/10.1016/j.vaa.2018.08.005>. Accessed: Dec. 20, 2019. doi: 10.1016/j.vaa.2018.08.005.

SOLANO, A, M., et al. Behavioural and cardiorespiratory effects of a constant rate infusion of medetomidine and morphine for sedation during standing laparoscopy in horses. Equine Veterinary
Journal. v.41, p.2153-2159, 2009. Available from: <https://doi. org/10.2746/042516408X342984>. Accessed: Dec. 20, 2019. doi: $10.2746 / 042516408 X 342984$.

TAINTOR, J., et al. Effect of Tranquilization or Sedation on the Gait of Lame Horses. Journal of Equine Veterinary Science. v.43, p.97-100, 2016. Available from: <https://doi.org/10.1016/j. jevs.2016.04.092>. Accessed: Dec. 20, 2019. doi: 10.1016/j. jevs.2016.04.092.

TAYLOR, P., et al. Evaluation of sedation for standing clinical procedures in horses using detomidine combined with buprenorphine. Veterinary Anaesthesia and Analgesia. v.41, p.14-24, 2014. Available from: <https://doi.org/1010.1111/ vaa.12055>. Accessed: Dec. 20, 2019. doi: 10.1111/vaa.12055 